\title{
Methacrylated Chitosan Based UV Curable Support for Enzyme Immobilization
}

\author{
Gülay Bayramoğlua* \\ ${ }^{a}$ Faculty of Engineering, Department of Polymer Engineering, Yalova University, 77100 Yalova, Turkey
}

Received: October 23, 2016; Accepted: January 19, 2017

\begin{abstract}
UV curing is simple, fast and effective procedure for enzyme immobilization with minimized enzymatic activity. UV-curable methacrylated chitosan is here proposed as a support material for immobilization of lipase. The morphology of the polymeric support was characterized by scanning electron microscopy (SEM). Both covalently (CIL) and physically (PIL) immobilized enzyme is analyzed in terms of enzymatic activity as a function of reusability, $\mathrm{pH}$, storage, as well as stability under various experimental conditions. The recovery of activity of lipases immobilized onto a photocrosslinked polymer network was $82.0 \%$ and $70.0 \%$ for CIL and PIL, respectively. The optimum pH value for the free lipase was at $\mathrm{pH}$ 6.0. The optimum $\mathrm{pH}$ of the both CIL and PIL was shifted to $\mathrm{pH}$ 7.0. Immobilization increased the thermostability of the lipase from $50{ }^{\circ} \mathrm{C}$ to $62^{\circ} \mathrm{C}$. The free enzyme lost all its activity within 15 days. Repeated batch experiments show that about $61 \%$ of the enzyme activity of CIL and $41 \%$ of PIL was retained after 8 cycles.
\end{abstract}

Keywords: Methacrylated chitosan, Enzyme immobilization, Lipase, Enzyme activity

\section{Introduction}

Enzymes, compared to conventional chemical catalysts, exhibit a number of features that make them attractive catalysts such as high level of catalytic efficiency and degree of specificity, easy removal from contaminated streams and operating at mild conditions of temperature, $\mathrm{pH}$ and pressure ${ }^{1,2}$. In addition to these advantages, they have some drawbacks such as high cost, instability of their structures out of its natural source, inability of recovery in the active form from reaction mixture for reuse and short lifetime $\mathrm{e}^{3,4}$. Immobilization is localization of enzyme molecules in/on a solid support for continuous catalytic process and it is an effective method to improve almost all the enzyme properties, if properly designed ${ }^{5,6}$. The support is one of the major component of an immobilized enzyme system ${ }^{[7]}$. The characteristics of the support are of paramount importance in determining the performance of the immobilized enzyme system $^{7,8}$. An ideal support require some properties like high mechanical stability, hydrophobicity, biocompatibility, inertness toward enzymes, resistance to bacterial attacks and availability at low cost are the important ${ }^{9,10}$. There are three main categories of support material as lipophilic synthetic organic polymers such as polystyrene and polyacrylamide, hydrophilic biopolymer based on natural polysaccharides such as cellulose and dextran, and an inorganic solid such as glass and iron oxide ${ }^{7,11-14}$. In spite of the many advantages of inorganic carriers (e.g., high stability against physical,

* e-mail: gulayb@yalova.edu.tr chemical, and microbial degradation), most of the applications are performed with organic matrices.

Lipase which is one of the extensively used, cheap and non-microbial enzymes, plays a key role in dietary fat absorption in the intestine. Lipases have been used for hydrolysis of esters, the synthesis of esters in organic solvents and acylating amines for the formation of amide bonds ${ }^{15}$. In the hydrolysis reaction of water-insoluble esters such as long chain triglycerides lipases act as a catalyst and convert triglycerides into polar molecules that are able to cross the brush border membrane of enterocytes as mixed micelles with bile salts ${ }^{16}$.

It is well known that lipases have a high affinity for hydrophobic surfaces and most of them express higher catalytic activity towards poorly soluable substrates. This is a consequence of the phenomenon called interfacial activation ${ }^{17}$. In most cases, the active site of the lipase is covered by short amphiphathic $\alpha$-helix called the lid (closed form) make it inaccessible in the medium ${ }^{18}$. The lid might open with an interaction with a hydrophobic phase which allow access of the substrate to the catalytic site ${ }^{19}$. Due to the movement of the lid, the lipase is absorbed on any hydrophobic surface.

Chitosan is a partially $\mathrm{N}$-deacetylated derivative of chitin, which is found on the walls of the fungi and on the shells of shellfish (mostly crabs, shrimps, lobsters and krills) ${ }^{1}$. Due to its biodegradable, biocompatible, antibacterial, nontoxic and wound-healing properties chitosan has been used in biomedical applications such as pharmaceutics, drug delivery systems, wound dressing materials, and tissue engineering applications ${ }^{20,21}$. Also, these properties make chitosan promising 
matrix for enzyme immobilization systems. Unfortunately, the poor solubility in both water and organic solvents is the major drawback of the chitosan. To improve the organic solubility of chitosan, many attempts have done on the modification of chitosan owing to both reactive amino and hydroxyl groups ${ }^{22-25}$.

The objective of the present study was to offer a UV curable rigid support for enzyme immobilization. UV curing is a simple and convenient method with low energy consumption and no solvent emission. Due to the short curing times ( 30 seconds to 2 minutes) it cause less damage to the catalytic activity of enzyme during immobilization process $^{26}$. For this purpose chitosan was modified with 2-isocayanatoethyl methacrylate and by this way a polymer containing urethane linkages and carbon-carbon double bonds was obtained. Also, polyethylene glycol mono acrylate (PEGMA) having free hydroxyl group, activated with 1,1- carbonyldiimidazole (CDI) and then reacted with the amine group of lipase enzyme to gain carbon-carbon double bonds. It is known that PEGMA can be activated by generating a reactive imidazole carbamate linkage between free hydroxyl groups and a CDI molecule ${ }^{27}$. The amine groups of the lipase enzyme carry out a nucleophilic attack to the remaining imidazole ring on the PEGMA-CDI molecule then forms a stable carbamate linkage.

After the tethering of lipase with PEGMA was successfully accomplished, mixture of methacrylated chitosan and lipase tethered polyethyleneglycol mono acrylate was crosslinked via UV radiation. Enzymatic activity of lipase, optimum $\mathrm{pH}$ and temperature, storage stability and reusability of covalently immobilized lipase were determined.

\section{Experimental}

\subsection{Materials}

Poly(ethylene glycol) monoacrylate [PEGMA] $(\mathrm{Mn}=375)$, poly (ethylene glycol) diacrylate [PEGDA] $(\mathrm{Mn}=575)$ and copper sulfate $\left(\mathrm{CuSO}_{4}\right)$ were all purchased from Sigma-Aldrich. Chitosan was also purchased from Sigma-Aldrich. Its weight-average molecular weight was $320 \mathrm{kDa}$ and degree of deacetylation was about $88 \%$. 1,1- carbonyldiimidazole (CDI) was purchased from Fluka. The photoinitiator 1-hydroxycyclohexyl- phenyl-ketone was obtained from Ciba Speciality Chemicals. Lipase from porcine pancreas $\left(16,5 \mathrm{U} \mathrm{mg}^{-1}\right.$, lyophilized from saline and calcium chloride, $\mathrm{pH} 7.0$, powder) was purchased from AppliChem. All other chemicals were of analytical grade and were purchased from Merck AG. Freshly double distilled water was used throughout.

\subsection{Protection of amino groups}

Chitosan (2 g) was dissolved in $100 \mathrm{~mL} 2 \%$ acetic acid solution in a $250 \mathrm{~mL}$ beaker. After chitosan was homogeneously dissolved, $1 \mathrm{M} \mathrm{CuSO}_{4}(100 \mathrm{~mL})$ solution was added slowly to form chitosan-copper complexes. After 30 min precipitated complexes were filtered washed with water to remove unreacted copper ions. They were grinded wet and washed with acetone; immersed with ether for $24 \mathrm{~h}$. After that they were filtered and immersed in fresh dry ether for another $12 \mathrm{~h}$ to remove the water; put in $50 \mathrm{~mL}$ anhydrous dimethylformamide (DMF).

\subsection{Methacrylation of Chitosan}

Chitosan which amino groups were protected in DMF was poured into $250 \mathrm{~mL}$ of flame dried three-necked roundbottom flask, equipped with a nitrogen inlet and a dropping funnel. After loading (2.4 mL) 2-isocyanatoethyl methacrylate (IEM), was added drop wise into the well-stirred reaction mixture. The reaction mixture was kept at $60^{\circ} \mathrm{C}$ for 6 hours. Disappearance of the characteristic -NCO peak at 2275 $\mathrm{cm}^{-1}$ in the FT-IR spectrum confirmed that the reaction was completed. Synthesis of methacrylated chitosan was illustrated in Scheme 1.

To remove protection groups, saturated sodium bicarbonate solution was added in the reaction mixture. The product was filtered, dealed with $100 \mathrm{~mL} \mathrm{2 \%}$ acetic acid solution and freeze dried. Structure of final product was given in Scheme 2.

\subsection{Preparation of Lipase Tethered PEGMA}

Polyethylene glycol mono acrylate (PEGMA, 11g) was poured into a three-necked $100 \mathrm{~mL}$ of a round-bottom flask equipped with a magnetic stirrer, a condenser and a nitrogen inlet. 1,1-Carbonyl-diimidazole (CDI, 5.5g) was dissolved in $50 \mathrm{~mL}$ of THF then added drop wise into the reaction mixture while mixing. The reaction mixture was kept at $40^{\circ} \mathrm{C}$ for 24 hours.

PEGMA-CDI (1g) was charged into $25 \mathrm{~mL}$ of a roundbottom flask equipped with a magnetic stirrer. Lipase solution with a concentration of $10 \mathrm{mg} / 5 \mathrm{~mL} \mathrm{H}_{2} \mathrm{O}$ was added to the PEGMA-CDI. The reaction mixture was stirred at room temperature for 24 hours. Then the product was transferred into a dark bottle and kept at $+4{ }^{\circ} \mathrm{C}$.

The imidazole carbamate groups of PEGMA-CDI can give a one pot substitution reaction with amino groups of the lipase enzyme in water without a $\mathrm{pH}$ arrangement and an inert atmosphere to form stable, uncharged carbamate linkages. It is known that the absence of charge on the linkages can prevent nonspecific adsorption by ion exchange ${ }^{28}$.

The lipase tethering to the PEGMA was illustrated in Scheme 3. After the immobilization completed, the reaction mixture was extracted with dichloromethane for three times. The lipase immobilization capacity of the polymeric support was defined as the amount of protein ( $\mathrm{mg}$ ) per gram of the polymeric support. Each reported value was the mean of three experiments at least, and the standard deviation was within ca. $\pm 5 \%$. 


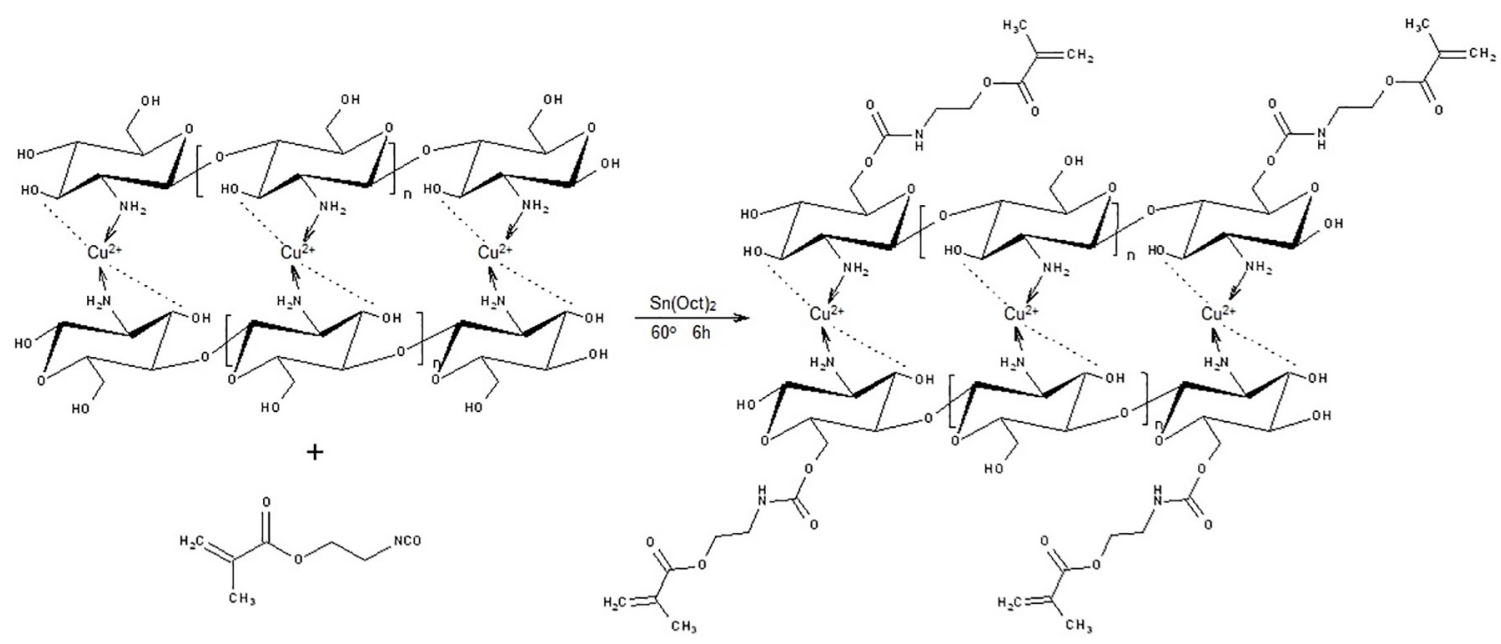

Scheme 1: Synthesis of methacrylated chitosan.

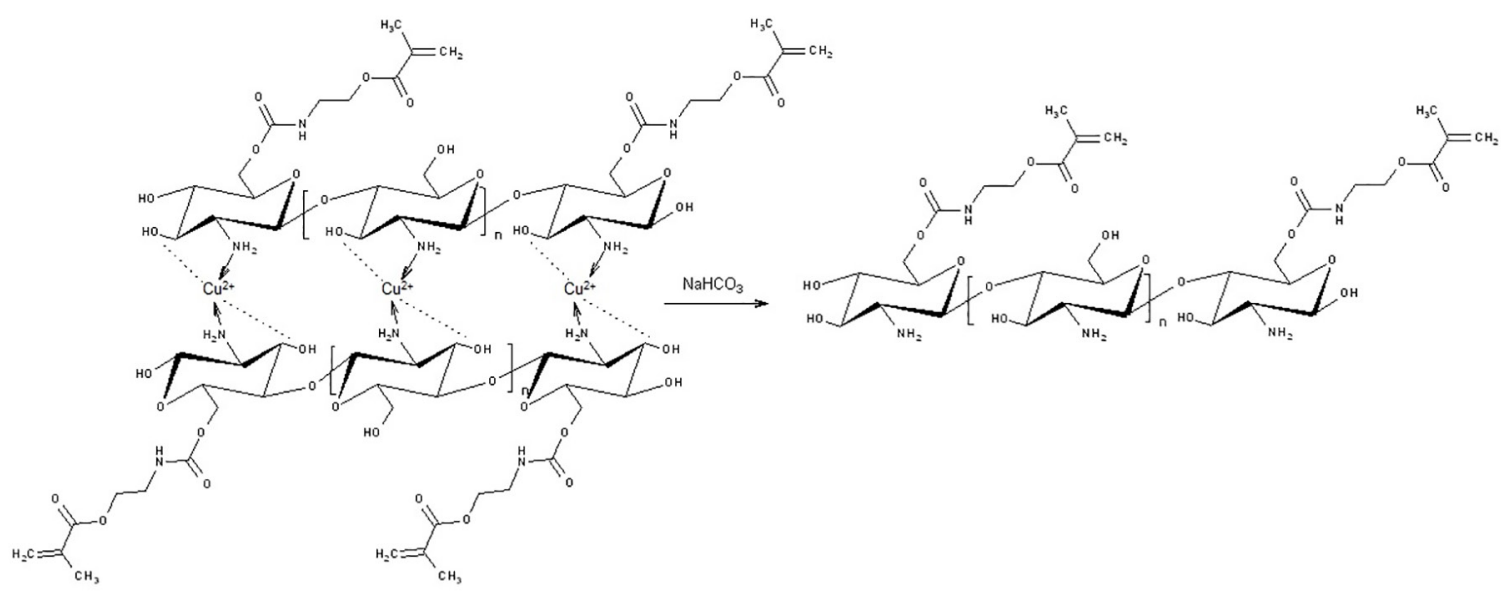

Scheme 2: Structure of final product.<smiles>C=CC(=O)OCCCCCCCCC(C)=O</smiles><smiles>C=CC(=O)OCCCOC(=O)NCCCOC(=O)n1ccnc1</smiles>

Scheme 3: The lipase tethering to the PEGMA.

\subsection{Preparation of polymeric support material}

Polymeric support containing lipase (CIL), was prepared by mixing lipase tethered polyethyleneglycol mono acrylate (PEGMA-Lipase) (10 wt \%), methacrylated chitosan (70 wt $\%)$, polyethyleneglycol diacrylate (PEGDA) (20 wt \%) and photoinitiator (Irgacure 184) (3\% of total weight).

Besides, another formulation (PIL) was prepared by mixing lipase without any modification as lipase (1\%), methacrylated chitosan $(80 \mathrm{wt} \%)$, polyethyleneglycol diacrylate (PEGDA) $(20 \mathrm{wt} \%)$ and photoinitiator (Irgacure184) (3\% of total

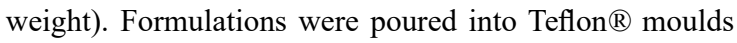
(diameter $5 \mathrm{~mm}$, height $3 \mathrm{~mm}$ ) and cured under high pressure UV lamp (OSRAM $300 \mathrm{~W}, \lambda_{\max }=365 \mathrm{~nm}$ ) for 3 minutes, and then polymeric discs were removed from the moulds.

\subsection{Characterization}

The structures of methacrylated chitosan and lipase tethered PEGMA were characterized by attenuated total 
reflectance Fourier Transform Infrared Spectroscopy (ATRFTIR). ATR-FTIR spectra were recorded on a Perkin Elmer Universal diamond ATR-FTIR spectrometer. Samples were placed on the ATR crystal and force is applied to the sample, pushing it onto the diamond surface, 20 scans were performed for each sample.

Morphology of the UV cured polymeric support was investigated by Scanningelectron microscopy (SEM). Prior to the SEM analysis, dried samples were broken in liquid nitrogen and the broken surfaces were coated with platinum approximately $300 \mathrm{~A}^{\mathrm{o}}$ using an Edwards S150 B sputter coater and observed by using a Philips XL30 ESEM-FEG/ EDAX system.

\subsection{Activity Assay of Free and Immobilized Lipase}

The activity of free and immobilized lipase was determined according to the method of Sigurgisladottir et al. with slight modification using $0.5 \mathrm{~g}$ of $p$-nitrophenyl palmitate ( $p$-NPP) dissolved in $100 \mathrm{~mL}$ of ethanol as substrate ${ }^{29}$. The increase in absorbance at $410 \mathrm{~nm}$ caused by the release of $p$-nitrophenol in the hydrolysis of $p$-NPP was measured spectrophotometrically. The reaction mixture was prepared by mixing $1 \mathrm{~mL}$ of $0.5 \%(\mathrm{w} / \mathrm{v}) p$-NPP solution, $1 \mathrm{~mL} 0.05$ M PBS (pH 8.0) and free lipase of $0.1 \mathrm{~mL}(10 \mathrm{mg} / 100 \mathrm{~mL})$ or $200 \mathrm{mg}$ of immobilized enzyme and incubated for $5 \mathrm{~min}$ at $30{ }^{\circ} \mathrm{C}$. The reaction was terminated by addition of $2 \mathrm{~mL}$ $0.5 \mathrm{~N} \mathrm{Na}_{2} \mathrm{CO}_{3}$ after $2 \mathrm{~min}$. The mixture was centrifuged for $10 \mathrm{~min}$ at $10,000 \mathrm{rpm} .0,5 \mathrm{~mL}$ clarified solution was diluted with 10 -folds with distilled water. Absorbance of the solution due to the release of p-nitrophenol was measured at 410 $\mathrm{nm}$ in a UV-vis spectrophotometer (Shimadzu, UV 1800, UV-vis spectrophotometer). Standard curve of $p$-NPP was drawn in the range of 1.65-13.0 mM. Activities of enzymes were determined by using the slope of the calibration curve. Experiments were carried out in triplicate and standard error was never over $5 \%$.

\subsection{Protein determination}

Dissolved protein concentration was determined according to the Lowry et al. (1951) method. A calibration curve prepared with bovine serum albumin (BSA) solution. The amount of bound protein per weight of support was calculated from the difference between the loaded protein and the protein remaining in the supernatant.

\subsection{Immobilization Yield}

The activity yield remaining after immobilization was defined as follows:

Activity yield $(\%)=C / A \times 100$

Immobilization yield $(\%)=A-B / A \times 100$ where $\mathrm{A}$ is the total activity of enzyme added in the initial immobilization solution; $\mathrm{B}$, the activity of the residual enzyme in the immobilization and washing solutions after the immobilization procedure; $\mathrm{C}$, the activity of the immobilized enzyme.

\subsection{Effect of $p H$ and temperature on the activity}

The effect of $\mathrm{pH}$ on the free and immobilized lipase activity was performed by varying the $\mathrm{pH}$ of the standard test between 4.0 and 9.0 at $37^{\circ} \mathrm{C}$. The assays were allowed to take place in $0.1 \mathrm{M}$ potassium phosphate buffers. The effect of temperature was assayed by a standard activity assay in the temperature range from 40 to $80^{\circ} \mathrm{C}$ at optimum $\mathrm{pH}$. The samples were removed after $5 \mathrm{~min}$ time intervals and assayed for residual enzyme activity.

\subsection{Reusability and Storage Stability}

Reusability measurements of immobilized enzyme samples were carried on after each reaction run. Samples were removed from reaction medium, washed with PBS to remove residual substrate then reintroduced into fresh medium. After each run enzyme activity was assayed at optimum condition.

The storage stabilities of free and immobilized lipase were measured by calculating the residual activity after 30 days at $4{ }^{\circ} \mathrm{C}$. During these days free and immobilized lipase were stored in PBS solution (0.05 M, pH 8.0). The residual activities of free and immobilized lipase were determined as described above section.

\subsection{Thermal Stability of Immobilized and Free lipase enzymes}

Thermal stabilities of the free and immobilized lipase were examined by pre-incubating free enzyme, PIL and CIL samples at the specified temperature at $50^{\circ} \mathrm{C}$ for 8 hours in the absence of the substrate. These enzyme preparations were then equilibrated at the perspective temperature and $\mathrm{pH}$ optimum for their activity before starting the assay.

\section{Results and Discussion}

\subsection{Characterization Studies}

Methacrylated chitosan was synthesized by reacting its hydroxyl groups with 2-isocyanatoethyl methacrylate in the presence of dibutyl tin dilaurate (T12) as a catalyst. For methacrylated chitosan synthesis, 2-isocyanatoethyl methacrylate (IEM), equivalent to of theoretical reactive group (hydroxyl and amine) content of chitosan, was used to obtain terminal methacrylic groups. The ATR-FTIR spectra of chitosan and its derivative were shown in (Figure 1). 
Methacrylated chitosan shows absorption bands at 1635 and $815 \mathrm{~cm}^{-1}$ assigned to the $\mathrm{C}=\mathrm{C}$ double bands due to methacrylation. Disappearance of the characteristic isocyanate band at $2275 \mathrm{~cm}^{-1}$ and $\mathrm{N}-\mathrm{H}$ and $\mathrm{O}-\mathrm{H}$ stretching vibration band at $3430 \mathrm{~cm}^{-1}$, formation of new bands at $1505 \mathrm{~cm}^{-1}$ and $1673 \mathrm{~cm}^{-1}$ which belong to $\mathrm{C}-\mathrm{N}$ stretching and $\mathrm{N}-\mathrm{H}$ bending and band at $1750 \mathrm{~cm}^{-1}$ belonging to carbonyl groups confirmed the expected structure.

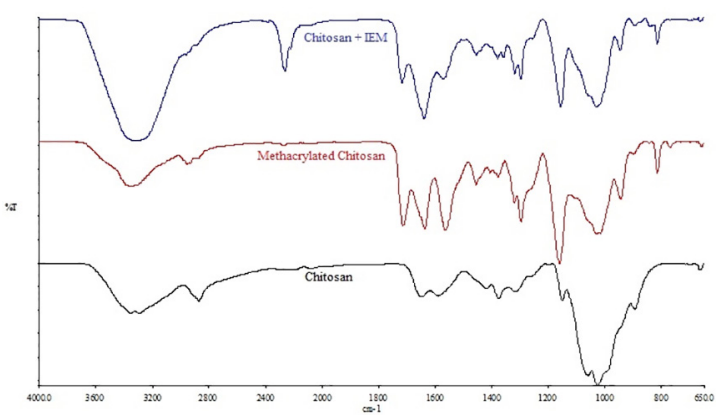

Figure 1: ATR-FTIR spectra of chitosan and methacrylated chitosan.

The SEM micrographs of the fracture surface morphology of polymeric support before and after enzyme immobilization was shown in Figure 2. One can see that polymeric support has a uniform and crack-free surface before enzyme immobilization (Figure 2a). After immobilization process, the surface morphology of the polymeric support was changed significantly (Figure 2b) and it can be clearly seen the attachment of the enzyme to the polymeric support.

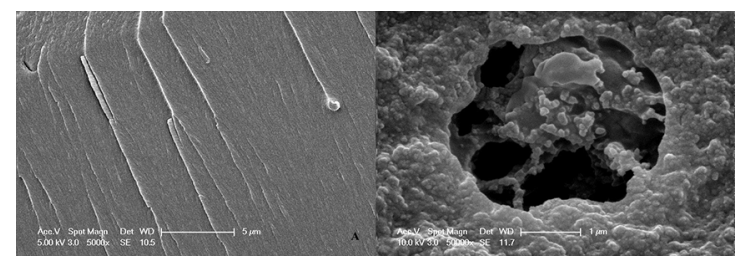

Figure 2: Scanning electron micrographs of (A) the polymeric support (B) immobilized enyzme on polymer.

\subsection{Lipase immobilization and characterization}

Lipase immobilization on polymeric support was performed with two different methods. One of the methods involves an enzyme binding on the PEGMA via hydroxyl groups and the other method involves direct mixing enzyme into mixture. It is known that high enzyme efficiency and activity yield depends on the method of immobilization.

When recovered activity of the immobilized enzyme is analyzed (ratio of specific activity of the immobilized enzyme and of the free one), it seems that the highest immobilization yield of $82 \%$ and bound enzyme activity of $74.0 \mathrm{U} \mathrm{mg}^{-1}$ were obtained with covalent attachment of enzyme to the support. When lipase was used without tethering to the PEGMA, immobilization yield and bound enzyme activity were found to be $70 \%$ and $59 \mathrm{U} \mathrm{mg}^{-1}$ respectively. It is possibly due to mass transfer problems associated with diffusion of substrate and product into the support material and access to the enzyme's active site. Because in this method enzyme immobilized into polymer physically and became entrapped into polymer chains without any homogeneity while PEGMA-Lipase incorporate polymer chains with more order.

\subsection{Effect of $p H$ on Immobilized and Free lipase enzymes}

It is known that when the enzyme immobilized, it becomes more stable but environmental parameters influence the enzyme activity whether or not immobilized. $\mathrm{pH}$ is one of the important parameter that affect the enzyme activity in aqueous solutions. A small change in $\mathrm{pH}$ of the medium may cause denaturation and loss of activity. When the immobilization of the enzyme was performed conformational chances which results variation of optimum $\mathrm{pH}$ occurs. Type of the support, activation method and immobilization method are the main factors that affect the optimum conditions for maximum enzyme activity of the enzyme whether immobilized or not ${ }^{11}$.

The effect of $\mathrm{pH}$ on the activities of CIL and PIL was measured in $\mathrm{PBS}$ at $37^{\circ} \mathrm{C}$ at different $\mathrm{pH}$ values ranging from 4 to 9 during 15 min incubation periods. The relative activity was given in (Figure 4) as a function of $\mathrm{pH}$. As can be seen from (Figure 3 ) that the optimum $\mathrm{pH}$ for immobilized lipase (both CIL and PIL) shifted from 6.0 to 7.0 when compared with free lipase. This shift relies on upon the enzyme reaction and in addition on the structure of the polymeric support.

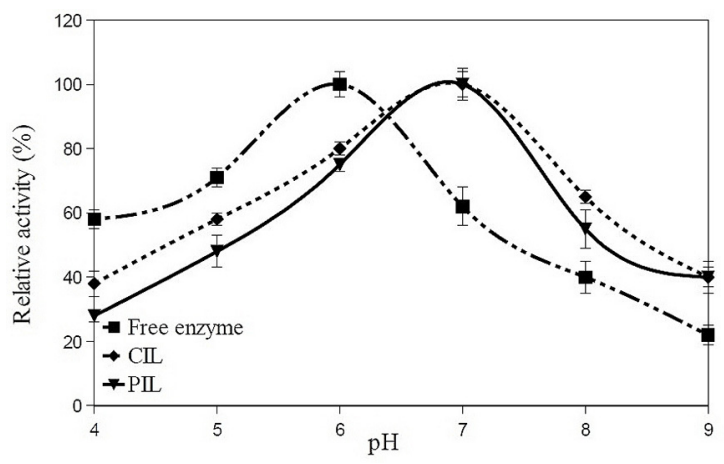

Figure 3: The effect of PH on enzyme stability.

\subsection{Effect of Temperature on the Activity}

In the present case, the operating temperature of immobilized enzyme was raised from $50^{\circ} \mathrm{C}$ to $60^{\circ} \mathrm{C}$. The effect of temperature on the activity of free and immobilized lipases for $p$-NPP hydrolysis at $\mathrm{pH} 7.0$ in temperature range of $40-80^{\circ} \mathrm{C}$ is shown in (Figure 4). It was found that the optimum temperature for the free lipase was found to be 50 ${ }^{\circ} \mathrm{C}$, while it shifted to $62{ }^{\circ} \mathrm{C}$ for CIL and PIL. The extended maximum temperature range revealed the higher thermal stability of the immobilized enzyme. For enzymes it is known 


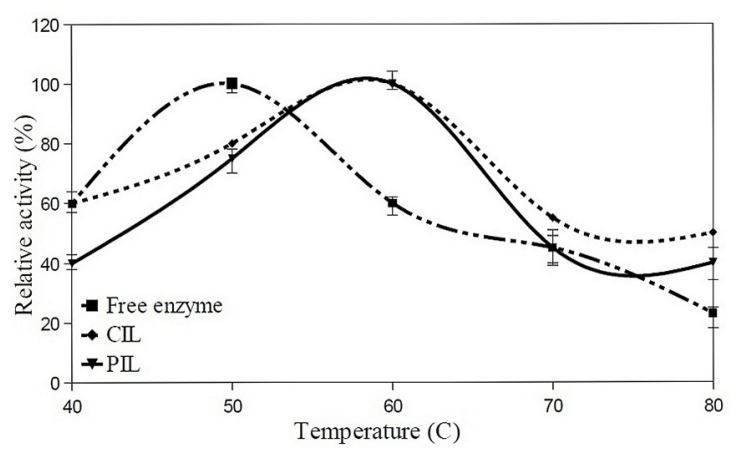

Figure 4: The effect of temperature on enzyme stability.

that higher temperatures lead to breaking of the interactions which are responsible for proper globular, catalytic active structure. Cross linking of UV curable resin provide more rigid external backbone for enzyme molecules and restrict the breaking of the interactions. By this way, thermal stability of the enzyme increases.

\subsection{Thermal Stability of Immobilized and Free lipase enzymes}

Free and immobilized enzymes were placed in the buffer solution of optimum $\mathrm{pH}$ and incubated at $50{ }^{\circ} \mathrm{C}$ for different time intervals $(0-8 \mathrm{~h})$.

Thermal stability of the free and immobilized lipase was examined by preincubating these preparations at the specified temperature at $50^{\circ} \mathrm{C}$ for 8 hours in the absence of the substrate. These enzyme preparations were then equilibrated at the perspective temperature and $\mathrm{pH}$ optimum for their activity before starting the assay.

The result presented in (Figure 5) show that lipase activity was improved by immobilization. The free enzyme lost $90 \%$ of its activity at $50^{\circ} \mathrm{C}$ for $8 \mathrm{~h}$. In contrast, immobilized enzymes conserve more than $37 \%$ and $44 \%$ of their activities for PIL and CIL, respectively. The greater stability of the immobilized enzyme may be ascribed to the stabilizing effects of immobilization. Also, there is considerable evidence that enzyme activity is dependent upon enzyme flexibility ${ }^{30}$. For the samples of PIL, enzyme was only entrapped within micro spaces formed in the matrix structures not chemically bond. But for the samples of CIL, enzyme was covalently attached to the polymeric matrix from multi points. Both of the two immobilization methods and rigid polymeric support create conformational limitation on enzyme movement which led higher thermal stabilities.

\subsection{Reusability and Storage Stability}

Reusability of an immobilized enzyme is one of the most important criteria in industrial or preparative applications because it defines the operational stability of the enzyme.

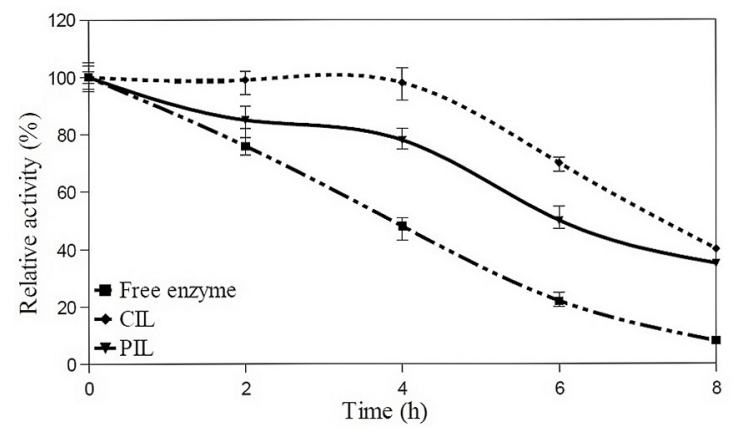

Figure 5: Thermal stability of the free and immobilized lipase at $50{ }^{\circ} \mathrm{C}$ for different time intervals $(0-8 \mathrm{~h})$.

To evaluate the reusability of the immobilized lipase, the polymeric supports was washed with PBS after one catalysis run and reintroduced into a fresh $p$-NPP solution for another hydrolysis at $50{ }^{\circ} \mathrm{C}$ The activity of freshly prepared supports in the first run was defined as $100 \%$. It can be seen in (Figure 6) that the activity of the immobilized lipase decreases with the repeated use. The residual activity of the immobilized lipase was about $41 \%$ after 8 cycles for PIL and $46 \%$ after 10 cycles for CIL.

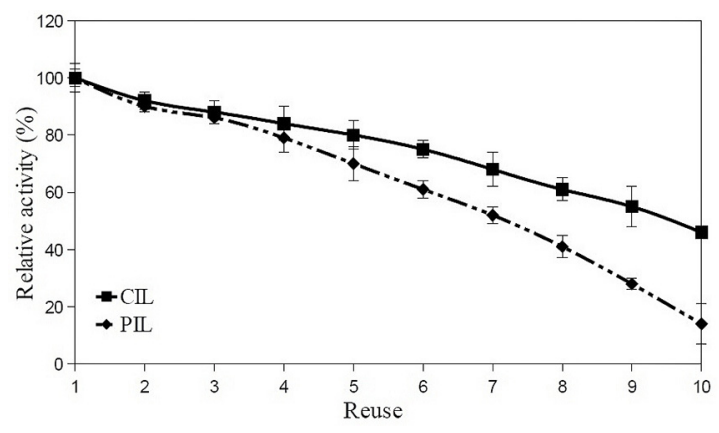

Figure 6: Reuse capabilities of CIL and PIL.

This might be mainly due to the inactivation of the enzyme caused by the denaturation of the protein and the leakage of the protein from the polymeric support. Another possible explanation is damage of the polymeric support during repeated use.

(Figure 7) shows the storage stability of free and immobilized lipase at $4{ }^{\circ} \mathrm{C}$ for 30 days of storage. The enzyme activity was measured every day. The residual activity of the enzyme was given in (Figure 7) as a function of time. These results indicate that under the same storage conditions, the activity of CIL and PIL decreased at a slower rate than free lipase. Upon 30 days of storage, the activity of CIL and PIL remained more than $47 \%$ and $61 \%$ at $4^{\circ} \mathrm{C}$, respectively. However, the activity of free enzyme only remained MM\%. Thus, free lipase exhibits the lowest stability, while immobilized lipases exhibit higher stabilities. The severe decrease in activity of free lipase and just immobilized lipase might be due to 
protein conformational changes. As we mentioned before, with the immobilization and cross linking, lipase attach to the polymeric support which provide protective environment and gain more rigid external backbone. This rigid backbone protect the enzyme from the possible distortion effects of the media. Thus, CIL and PIL have higher storage stability compared to that of its free form.

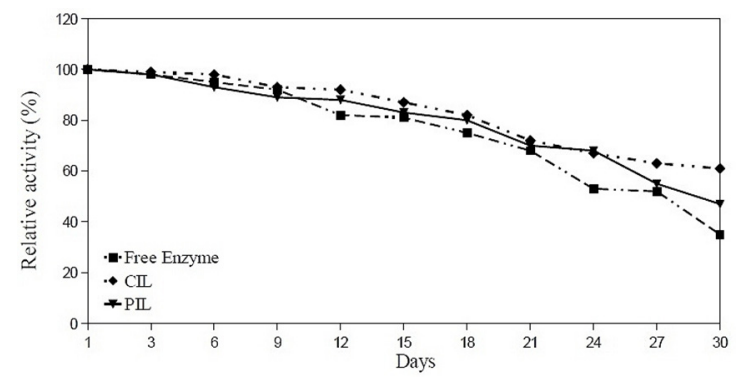

Figure 7: Storage stability of free and immobilized lipases.

\section{Conclusion}

UV curable methacrylated chitosan support was prepared for lipase immobilization. Immobilization was performed rapidly using different immobilization methods under very mild conditions. ATR-FTIR spectrum proved that the chemical modification of chitosan and covalent attachment of the enzyme was carried out successfully. Both immobilization methods have influenced the enzyme characteristics in a good manner. Optimum $\mathrm{pH}$ and temperature were increased to 7.0 and $62{ }^{\circ} \mathrm{C}$, respectively.

\section{References}

1. Krajewska B.Application of chitin- and chitosan-based materials for enzyme immobilizations: a review. Enzyme and Microbial Technology. 2004;35(2-3):126-139.

2. Ye P, Xu ZK, Che AF, Wu J, Seta P. Chitosan-tethered poly(acrylonitrile-co-maleic acid) hollow fiber membrane for lipase immobilization. Biomaterials. 2005;26(32):6394-6403.

3. Akdemir ZS, Demir S, Kahraman MV, Apohan NK. Preparation and characterization of UV-curable polymeric support for covalent immobilization of xylanase enzyme. Journal of Molecular Catalysis B: Enzymatic. 2011;68(1):104-108.

4. Reshmi V, Sanjay V, Sugunan S. Enhanced activity and stability of $\alpha$-amylase immobilized on alumina. Catalysis Communications. 2006;7(7):460-465.

5. Kragl U. Immobilized Enzymes and Membrane Reactor. In: Godfrey T, Wet S, eds. Industrial Enzymology. London: Macmillan Press; 1996.

6. Bayramoğlu G, Karakışla M, Altıntaş B, Metin AU, Saçak M, Arıca MY. Polyaniline grafted polyacylonitrile conductive composite fibers for reversible immobilization of enzymes: Stability and catalytic properties of invertase. Process Biochemistry. 2009;44(8):880-885.
7. Santos JCS, Barbosa O, Ortiz C, Berenguer-Murcia A, Rodrigues RC, Fernandez-Lafuente R. Importance of the Support Properties for Immobilization or Purification of Enzymes. Chem CatChem. 2015;7(16):2413-2432.

8. Brena BM, Batista-Viera F. Immobilization of Enzymes. In: Guisan JM, ed. Immobilization of Enzymes and Cells. $2^{\text {nd }}$ ed. Totowa: Humana Press; 2006. p. 15-30.

9. Brodelius P, Mosbach K. Immobilization Techniques for Cells/ Organelles. In: Mosbach K, ed. Methods in Enzymology. Vol 135. London: Academic Press; 1987. p. 173-454.

10. Buchholz K, Klein J. Characterization of Immobilized Biocatalysts. In: Mosbach K, ed. Methods in Enzymology. Vol 135. London: Academic Press: London; 1987. p. 3-30.

11. Worsfold PJ. Classification and chemical characteristics of immobilized enzymes. Pure \& Applied Chemistry. 1995;67(4):597-600.

12. Sheldon RA. Enzyme Immobilization: The Quest for Optimum Performance. Advanced Synthesis \& Catalysis. 2007;349(8-9):1289-1307.

13. Rodrigues RC, Hernandez K, Barbosa O, Rueda N, GarciaGalan C, Santos JCS, et al. Immobilization of Proteins in Poly-Styrene-Divinylbenzene Matrices: Functional Properties and Applications. Current Organic Chemistry. 2015;19(17):17071718.

14. Santos JCS, Rueda N, Barbosa O, Fernández-Sánchez J, Medina-Castillo AL, Ramón-Márquez T, et al. Characterization of supports activated with divinyl sulfone as a tool to immobilize and stabilize enzymes via multipoint covalent attachment. Application to chymotrypsin. RSC Advances. 2015;5(27):2063920649.

15. Sandström AG. Protein Engineering of Candida antarctica Lipase A: Enhancing Enzyme Properties by Evolutionary and Semi-Rational Methods. [Doctoral thesis]. Stockholm: Stockholm University, Faculty of Science, Department of Organic Chemistry; 2010.

16. Hermoso J, Pignol D, Kerfelec B, Crenon I, Chapus C, Fontecilla-Camps JC. Lipase activation by nonionic detergents. The crystal structure of the porcine lipase-colipase-tetraethylene glycol monooctyl ether complex. The Journal of Biological Chemistry. 1996;271(30):18007-18016.

17. Manoel EA, Santos JCS, Freire DMG, Rueda N, FernandezLafuente R. Immobilization of lipases on hydrophobic supports involves the open form of the enzyme. Enzyme and Microbial Technology. 2015;71:53-57.

18. Hjorth A, Carriere F, Cudrey C, Woldike H, Boel E, Lawson $\mathrm{DM}$, et al. A structural domain (the lid) found in pancreatic lipases is absent in the guinea pig (phospho)lipase. Biochemistry. 1993;32(18):4702-4707.

19. Santos JCS, Rueda N, Goncalves LRB, Fernandez-Lafuente R. Tuning the catalytic properties of lipases immobilized on divinylsulfone activated agarose by altering its nanoenvironment. Enzyme and Microbial Technology. 2015;77:1-7

20. Monteiro Jr OAC, Airoldi C. Some Thermodynamic Data on Copper-Chitin and Copper-Chitosan Biopolymer Interactions. Journal of Colloid and Interface Science. 1999;212(2):212-219. 
21. Payne GF, Sun WQ. Tyrosinase Reaction and Subsequent Chitosan Adsorption for Selective Removal of a Contaminant from a Fermentation Recycle Stream. Applied and Environmental Microbiology. 1994;60(2):397-401.

22. Mourya VK, Inamdar NN, Tiwari A. Carboxymethyl Chitosan And Its Applications. Advanced Materials Letters. 2010;1(1):11-33.

23. Holappa J, Nevalainen T, Savolainen J, Soininen P, Elomaa M, Safin R, et al. Synthesis and Characterization of Chitosan $N$-Betainates Having Various Degrees of Substitution. Macromolecules. 2004;37(8):2784-2789.

24. Nishimura SI, Kohgo O, Kurita K, Kuzuhara H. Chemospecific manipulations of a rigid polysaccharide: syntheses of novel chitosan derivatives with excellent solubility in common organic solvents by regioselective chemical modifications. Macromolecules.1991;24(17):4745-4748.

25. Kurita K, Kobayashi M, Munakata T, Ishii S, Nishimura SI. Synthesis of Non-Natural Branched Polysaccharides. Regioselective Introduction of $\alpha$-Mannoside Branches into Chitin. Chemistry Letters. 1994;23(11):2063-2066.
26. Kahraman MV, Bayramoğlu G, Kayaman-Apohan N, Güngör A. UV-curable methacrylated/fumaric acid modified epoxy as a potential support for enzyme immobilization. Reactive and Functional Polymers. 2007;67(2):97-103.

27. Bayramoğlu G, Kayaman-Apohan N, Kahraman MV, Karadenizli S, Kuruca SE, Güngör A. Preparation of bow tietype methacrylated poly(caprolactone-co-lactic acid) scaffolds: effect of collagen modification on cell growth. Polymers for Advanced Technologies. 2012;23(10):1403-1413.

28. Xu FJ, Neoh KG, Kang ET. Bioactive surfaces and biomaterials via atom transfer radical polymerization. Progress in Polymer Science. 2009;34(8):719-761.

29. Sigurisladóttir S, Konráòsdottır M, Jónsson A, Kristjánsson JK, Matthiasson E. Lipase activity of thermophilic bacteria from icelandic hot springs. Biotechnology Letters. 1993;15(4):361-366.

30. Daniel RM, Dines M, Petach HH. The denaturation and degradation of stable enzymes at high temperatures. Biochemical Journal. 1996;317(1):1-11. 